\title{
Effects of Increasing Levels of Palm Kernel Oil in the Feed of Finishing Lambs
}

\author{
Daniela Pionorio Vilaronga Castro ${ }^{1}$, Paulo Roberto Silveira Pimentel ${ }^{1}$, Jarbas Miguel da Silva Júnior ${ }^{1}{ }^{(\mathbb{C},}$ \\ Gercino Ferreira Virgínio Júnior ${ }^{1}{ }^{10}$, Ederson Américo de Andrade ${ }^{1}{ }^{1}$, Analívia Martins Barbosa ${ }^{1} \mathbb{D}^{1}$, \\ Elzânia Sales Pereira ${ }^{2}$, Claudio Vaz Di Mambro Ribeiro ${ }^{1}$, Leilson Rocha Bezerra ${ }^{3}$ (1) \\ and Ronaldo Lopes Oliveira ${ }^{1, *}$
}

check for updates

Citation: Castro, D.P.V.; Pimentel P.R.S.; da Silva Júnior, J.M.; Virgínio Júnior, G.F.; de Andrade, E.A.; Barbosa, A.M.; Pereira, E.S.; Ribeiro, C.V.D.M.; Bezerra, L.R.; Oliveira, R.L. Effects of Increasing Levels of Palm Kernel Oil in the Feed of Finishing Lambs. Animals 2022, 12, 427. https://doi.org/10.3390/ani12040427

Academic Editors: Aser García-Rodríguez and Idoia Goiri

Received: 16 November 2021 Accepted: 9 December 2021 Published: 11 February 2022

Publisher's Note: MDPI stays neutral with regard to jurisdictional claims in published maps and institutional affiliations.

Copyright: (C) 2022 by the authors. Licensee MDPI, Basel, Switzerland. This article is an open access article distributed under the terms and conditions of the Creative Commons Attribution (CC BY) license (https:// creativecommons.org/licenses/by/ $4.0 /)$.
1 Department of Animal Science, Federal University of Bahia, Salvador 40170110, BA, Brazil; danipionorio_zootecnia@hotmail.com (D.P.V.C.); paulorobertopimentel@zootecnista.com.br (P.R.S.P.); miguelreges@gmail.com (J.M.d.S.J.); gercino.ferreiravj@yahoo.com.br (G.F.V.J.); edersonzootec@gmail.com (E.A.d.A.); analiviabarbosa@gmail.com (A.M.B.); claudioribeiro@ufba.br (C.V.D.M.R.)

2 Department of Animal Science, Federal University of Ceara, Fortaleza 60021970, CE, Brazil; elzania@hotmail.com

3 Department of Animal Science, Federal University of Campina Grande, Patos 58708110, PB, Brazil; leilson@ufpi.edu.br

* Correspondence: ronaldooliveira@ufba.br

Simple Summary: Palm kernel oil (PKO) is extracted from an oleaginous seed fruit (Elaeis guineenses Jacq.) commonly cultivated in Brazil and can be used strategically as a ruminal fermentation modulator to improve animal performance. We conducted three experimental trials by increasing PKO levels in the diets of lambs. Although we observed low consumption of most nutrients, we also observed that feed conversion improved as the PKO inclusion level increased, indicating that the animals needed to consume less food to gain $1.0 \mathrm{~kg}$ of body weight. In addition, we observed that nutrient digestibility was not affected by the inclusion levels of PKO. We also did not observe differences in ruminal fermentation parameters but noted a reduction in the protozoan population. Therefore, we conclude that the inclusion of palm kernel oil may be beneficial to lambs and can lower the cost of feed in regions that contain an abundance of this byproduct.

Abstract: The aim of this study was to evaluate the effects of the inclusion of palm kernel oil $(\mathrm{PKO})$ in a lamb diet on nutrient intake, digestibility, ingestive behavior, nitrogen balance, blood metabolites, rumen fermentation parameters, and animal performance. Three experimental trials were conducted. The treatments consisted of varying levels of PKO included in the diet, with $\mathrm{PKO}_{\text {zero }}=$ no $\mathrm{PKO}$ inclusion, $\mathrm{PKO}_{1.3}=1.3 \%$ addition, $\mathrm{PKO}_{2.6}=2.6 \%$ addition, $\mathrm{PKO}_{3.9}=3.9 \%$ addition, and $\mathrm{PKO}_{5.2}=5.2 \%$ addition, based on the total dry matter $(\mathrm{DM})$ of the diet. With the inclusion of PKO in the diet, linear decreases in DM $(p<0.001)$, crude ash $(p<0.001)$, crude protein (CP) $(p<0.001)$, neutral detergent fiber (NDF) $(p<0.001)$, nonfibrous carbohydrate (NFC) $(p<0.001)$, and total digestible nutrient (TDN) $(p=0.021)$ intake were observed, as was an increase in ether extract (EE) intake $(p<0.001)$. The digestibility coefficients of NDF and NFC were not affected by PKO addition to the diet. However, the digestibility of DM $(p=0.035)$, EE $(p<0.001), \mathrm{CP}(p<0.001)$, and TDNs $(p<0.001)$ increased when PKO was added to the lambs' diet. Reductions in N intake $(p<0.001)$, fecal nitrogen excretion $(p<0.001)$, and microbial protein production $(p<0.001)$ were noted with increasing PKO levels. Serum cholesterol increased $(p<0.001)$ while serum GGT enzyme concentrations in the blood decreased $(p=0.048)$ with increasing PKO levels. PKO addition had no effect on total weight gain and average daily gain; however, feed conversion improved $(p=0.001)$ with increasing PKO levels. The intake, digestibility, ingestive behavior, and growth performance of lambs with $\mathrm{PKO}_{1.3}$ added to their diet were similar to animals that did not receive $\mathrm{PKO}$, meaning that PKO could be an alternative energy source for growing lambs because it does not harm animal performance and can lower the cost of feed. 


\section{Introduction}

The use of strategies to increase the efficiency of the production system promotes ruminal fermentation modulation through microbiota modification. Modulation can occur by removing groups of microorganisms, especially protozoa, which decrease the nutrients available to the animal [1]. According to Newbold and Ramos-Morales [2], the defaunation process is related to increased microbial growth efficiency due to decreased predation of bacteria by protozoa. Therefore, palm kernel oil is an interesting option for this purpose [3].

Palm kernel oil (PKO) is extracted from oleaginous seed fruits (Elaeis guineenses Jacq.), which are commonly found and cultivated in Brazil [4]. PKO is a source of medium-chain fatty acids, such as lauric acid, which has antimicrobial activity [5], exerting effects on bacteria [5-7] and protozoa [8,9]. As a result of its antiprotozoal activity, studies have been carried out to verify its effects on nutrient intake and digestibility, mainly in dairy cattle [8-11]. This inhibitory effect may be related to a lower microbial adhesion to the plant fiber caused by the lipids coating the fiber or to the possible direct cytotoxic effect of the fatty acids changing the lipid composition and physicochemical properties of the membranes, increasing the fluidity and permeability of the microbial cells [1,12-14]. Regarding the use of lauric acid for lambs, Machmüller and Kreuzer [15] observed no effect on the digestibility of dry matter and neutral detergent fiber when they provided increasing doses of coconut oil as a source of lauric acid to lambs; however, they identified an increase in crude protein digestibility as the concentration of lauric acid increased, and such effects were related to a decrease in the protozoan population.

The added PKO associated with corn oil in dairy cow diets increased milk production without decreasing intake or diet digestibility [3]. However, no information on palm kernel oil administration and its effects on lambs is available. Other studies using palm kernel cake have shown some benefits from its inclusion in lamb feed [16,17], which may indicate a positive impact of this oil when added to the diet. Thus, the aim of this study was to evaluate the effects of different levels of palm kernel oil in the diet of lambs, evaluating intake, performance, nutrient digestibility, ingestive behavior, and ruminal and blood parameters. Furthermore, we hypothesize that the inclusion of different levels may benefit nutrient digestibility and decrease the ruminal protozoan population.

\section{Materials and Methods}

\subsection{Experimental Diets and Animals}

The study was carried out at the experimental facilities of the School of Veterinary Medicine and Animal Science of the Federal University of Bahia (UFBA) in São Gonçalo dos Campos.

A total of 70 animals were included in three experimental trials. In all trials, the same experimental diets were used. The experimental diets were based on the inclusion of palm kernel oil (PKO; PalmFry, Jundiaí, Brazil) in the diet, with $\mathrm{PKO}_{\text {zero }}=$ no palm kernel oil addition, $\mathrm{PKO}_{1.3}=1.3 \%$ palm kernel oil addition, $\mathrm{PKO}_{2.6}=2.6 \%$ palm kernel oil addition, $\mathrm{PKO}_{3.9}=3.9 \%$ palm kernel oil addition, and $\mathrm{PKO}_{5.2}=5.2 \%$ palm kernel oil addition, and on the dry matter of the total diet.

The animals in all experimental trials were fed twice a day (08:00 and 16:00) a total mixed ration (TMR) diet, with feeding design ensuring 10-20\% refusals, and water was provided ad libitum. Tifton-85 hay (Cynodon sp.) chopped into particles of approximately $5 \mathrm{~cm}$ was included in the diets at a 40:60 roughage:concentrate ratio. The diet compositions are described in Table 1 . The diets were isonitrogenous and were formulated according to the NRC [18] to provide an average daily gain of $200 \mathrm{~g}$. 
Table 1. Ingredient proportions, chemical composition, and fatty acid profile of the experimental diets.

\begin{tabular}{|c|c|c|c|c|c|}
\hline & \multicolumn{5}{|c|}{ Palm Kernel Oil Levels (\% DM Total) } \\
\hline & 0 & 1.3 & 2.6 & 3.9 & 5.2 \\
\hline \multicolumn{6}{|c|}{ Ingredients (\% Total Diet) } \\
\hline Hay & 40.0 & 40.0 & 40.0 & 40.0 & 40.0 \\
\hline Ground corn & 42.5 & 41.0 & 39.6 & 38.1 & 36.6 \\
\hline Soybean meal & 16.0 & 16.2 & 16.3 & 16.5 & 16.7 \\
\hline Palm kernel oil & 0.0 & 1.30 & 2.60 & 3.90 & 5.19 \\
\hline Mineral mixture $^{1}$ & 1.50 & 1.50 & 1.50 & 1.50 & 1.50 \\
\hline \multicolumn{6}{|c|}{ Chemical Composition (\% Dry Matter) } \\
\hline Dry matter (\% fresh matter) & 86.8 & 86.9 & 87.1 & 87.3 & 87.5 \\
\hline Organic matter & 93.9 & 93.9 & 93.9 & 94.0 & 94.0 \\
\hline Crude ash & 6.1 & 6.1 & 6.1 & 6.0 & 6.0 \\
\hline Crude protein & 13.9 & 13.9 & 13.8 & 13.8 & 13.7 \\
\hline Ether extract & 1.40 & 2.66 & 3.92 & 5.18 & 6.44 \\
\hline Neutral Detergent Fiber ap & 36.6 & 36.5 & 36.4 & 36.3 & 36.2 \\
\hline Acid Detergent Fiber & 17.1 & 17.1 & 17.1 & 17.0 & 17.0 \\
\hline Non-Fibrous Carbohydrates ${ }^{2}$ & 42.0 & 40.1 & 39.8 & 38.7 & 37.6 \\
\hline \multicolumn{6}{|c|}{ Fatty Acid Profile (g/100 g Total Fat) } \\
\hline C 10:0 (Capric) & 0.38 & 2.00 & 2.36 & 2.58 & 2.78 \\
\hline C 12:0 (Lauric) & 3.92 & 28.20 & 33.94 & 36.46 & 38.61 \\
\hline C 14:0 (Myristic) & 2.84 & 10.62 & 11.77 & 13.00 & 14.20 \\
\hline C 16:0 (Palmitic) & 56.00 & 52.70 & 49.05 & 50.70 & 50.80 \\
\hline C 16:1 (Palmitoleic) & 0.42 & 0.34 & 0.35 & 0.34 & 0.32 \\
\hline C 18:0 (Stearic) & 9.80 & 9.74 & 9.02 & 7.35 & 9.56 \\
\hline C $18: 1^{\text {cis9 }}$ (Oleic) & 42.17 & 32.67 & 31.17 & 29.27 & 27.57 \\
\hline C $18: 2^{\text {cis9 cis12 }}$ (Linoleic) & 54.60 & 33.10 & 31.90 & 28.60 & 24.70 \\
\hline C 18:3n-3 (Linolenic) & 11.18 & 10.41 & 10.40 & 10.38 & 10.07 \\
\hline Others & 6.28 & 9.52 & 9.74 & 11.38 & 11.67 \\
\hline
\end{tabular}

${ }^{1}$ Assurance levels (per kilogram of active elements): $120 \mathrm{~g}$ of calcium, $87 \mathrm{~g}$ of phosphorus, $147 \mathrm{~g}$ of sodium, $18 \mathrm{~g}$ of sulfur, $590 \mathrm{mg}$ of copper, $40 \mathrm{mg}$ of cobalt, $20 \mathrm{mg}$ of chromium, $1800 \mathrm{mg}$ of iron, $80 \mathrm{mg}$ of iodine; $1300 \mathrm{mg}$ of manganese, $15 \mathrm{mg}$ of selenium; $3800 \mathrm{mg}$ of zinc, $300 \mathrm{mg}$ of molybdenum; maximum $870 \mathrm{mg}$ of fluoride. ${ }^{2} \mathrm{NFC}=100-\mathrm{NDF}_{\mathrm{ap}}-\mathrm{CP}-\mathrm{EE}$.

\subsection{Trial 1-Nutrient Intake, Blood Metabolites, Fatty Acids, and Chemical Diet Analysis}

Nutrient intake was evaluated in 40 noncastrated male Santa Inês lambs (body weight (BW) $25.73 \pm 4.01 \mathrm{~kg}$ ), which had been previously vaccinated and dewormed and were randomly assigned to groups according to an entirely randomized design, housed in individual stalls measuring $1.0 \mathrm{~m}^{2}$, and suspended in wooden slats with individual water and feed troughs, with a total of eight animals per treatment.

The evaluation period was $96 \mathrm{~d}$, and the first $15 \mathrm{~d}$ were intended for adaptation to the environment, management, and diets. The animals were weighed at the beginning of the experimental period and every $25 \mathrm{~d}$ to follow weight gain. Every day in the morning before feeding, the orts were collected and weighed to determine intake, allowing adjustments in the quantities to be offered. Every three days, a sample was collected for further chemical and bromatological analysis. At the end of the experimental period, the animals were weighed after a $16 \mathrm{~h}$ fast on solids and water to determine total weight gain (TWG), average daily gain (ADG), and the feed conversion ratio (FCR: the ratio between total feed intake and total weight gain).

Blood samples (i.e., $10 \mathrm{~mL}$ ) were collected by jugular venipuncture, on the last day of the experiment, using a vacutainer system in tubes free of anticoagulants. After collection, the blood samples were centrifuged (Centrilab ${ }^{\circledR}$ model CE3001, São Paulo, Brazil) at $5000 \times g$ for 20 min to obtain the serum, which was placed in Eppendorf tubes and stored in a freezer $\left(-20^{\circ} \mathrm{C}\right)$ for further analysis. The blood parameters were analyzed using specific commercial enzymatic kits from Labtest ${ }^{\circledR}$ Diagnostica S.A. (Lagoa Santa, Minas Gerais, Brazil) using a semiautomatic biochemical analyzer (BioPlus $2000^{\circledR}$, São Paulo, Brazil): albumin was measured with bromocresol green (Ref. 19); total cholesterol was 
measured by the cholesterol enzymatic method (Ref. 13); triglycerides were measured with glycerol phosphate oxidase (GOD; Ref. 87); the total protein concentration was measured by the biuret method (Ref. 99); and alanine aminotransferase (ALT; Ref. 108), aspartate aminotransferase (AST; Ref. 109) and gamma-glutamyltransferase (GGT; Ref. 105) were measured by UV IFCC kinetic assay.

The ingredient samples and refusals were predried at $55^{\circ} \mathrm{C}$ for $72 \mathrm{~h}$ and ground in a $1 \mathrm{~mm}$ sieve in a Wiley mill (Tecnal, City of Piracicaba, State of São Paulo, Brazil) for further laboratory analyses of dry matter (DM; AOAC method 930. 15), crude protein (CP; AOAC method 968.06), ether extract (EE; AOAC method 954.05), and crude ash (AOAC method 942.05). The neutral detergent fiber (NDF) and acid detergent fiber (ADF) contents were evaluated according to Van Soest et al. [19]. The NDF content was corrected for ash and protein $\left(\mathrm{NDF}_{\mathrm{ap}}\right)$ using thermostable alpha-amylase without sodium sulfite, and for residual ash [20] and residual nitrogenous compounds [21]. Nonfiber carbohydrate (NFC) contents were calculated as described by Weiss [22].

The fatty acid compositions of the experimental diets were determined according to Palmquist and Jenkins [23]. A total of $0.5 \mathrm{~g}$ of dry sample was weighed in duplicate into Pyrex-type test tubes with a Teflon cap. In each tube, $2 \mathrm{~mL}$ of hexane and $3 \mathrm{~mL}$ of $10 \%$ methanolic acetyl chloride were added. The tubes were capped, vortexed (Fisatom 772, São Paulo, Brazil), heated in a water bath at $90{ }^{\circ} \mathrm{C}$ for $2 \mathrm{~h}$, and then cooled. A total of $1 \mathrm{~mL}$ of hexane and $10 \mathrm{~mL}$ of $6 \% \mathrm{~K}_{2} \mathrm{CO}_{3}$ were added. Samples were again homogenized by vortexing. The tubes were centrifuged (Centribio 80-2B, Equipar Ltda., Paraná, Brazil) for $5 \mathrm{~min}$, and the solvent layer was collected and transferred to another test tube containing $1.0 \mathrm{~g}$ of $\mathrm{Na}_{2} \mathrm{SO}_{4}$ and activated charcoal. The tubes were centrifuged, and the supernatant was transferred to small vials for gas chromatography (GC).

Fatty acid methyl esters (FAMEs) were separated in a GC (Perkin Elmer Clarus 680) equipped with a flame ionization detector (GC-FID) and an ELITE-WAX fused silica capillary column $(30 \mathrm{~m} \times 0.32 \mathrm{~mm} \times 0.25 \mu \mathrm{m})$. The analysis parameters were as follows: the injector temperature was $250{ }^{\circ} \mathrm{C}$; the detector temperature was $280{ }^{\circ} \mathrm{C}$; and the column temperature was programmed at $150{ }^{\circ} \mathrm{C}$ for $16 \mathrm{~min}$, with increases of $2^{\circ} \mathrm{C}$ per minute up to $180{ }^{\circ} \mathrm{C}$ and maintenance of this temperature for $25 \mathrm{~min}$, followed by increases of $5{ }^{\circ} \mathrm{C}$ up to $210^{\circ} \mathrm{C}$, which was maintained for $25 \mathrm{~min}$. Helium gas was used as a carrier gas with a flow of $1 \mathrm{~mL} / \mathrm{min}$. The hydrogen gas flow rate was $30 \mathrm{~mL} /$ minute, and the synthetic air flow rate was $300 \mathrm{~mL} / \mathrm{min}$. Injections were performed in duplicate for each extraction, and the injection volume was $1 \mu \mathrm{L}$. FA was identified by comparing the retention times of the sample peaks with the retention time of the mixed standard FA (189-19, Sigma, St Louis, MO, USA). The results were quantified by area normalization and expressed in $\mathrm{g} / 100 \mathrm{~g}$ of FAME.

\subsection{Trial 2-Nutrient Digestibility, Nitrogen Balance and Ingestive Behavior}

For the second trial, 25 noncastrated male Santa Inês lambs (34.61 $\pm 2.61 \mathrm{~kg}$ BW) were distributed according to an entirely randomized design with five treatments and five repetitions. All animals had been previously vaccinated and dewormed and were housed in individual metabolic cages $(1.5 \mathrm{~m} \times 0.75 \mathrm{~m})$ with individual feed and water troughs, each of which had a system that allowed separate feces and urine collection.

The digestibility evaluation was performed for $21 \mathrm{~d}$, including $14 \mathrm{~d}$ for adaptation to the facilities and experimental diets and $7 \mathrm{~d}$ for collection of feces, urine, feed, and orts. The feed and ort samples were analyzed as previously described. Feces were collected in individual plates and weighed before the morning feeding. After total collection, the feces were weighed and a $20 \%$ portion was separated and dried in an oven with forced air circulation at $55{ }^{\circ} \mathrm{C}$ for $72 \mathrm{~h}$ and subsequently analyzed.

The total digestible nutrients were calculated according to NRC [24] using the digestible fractions of nonfiber carbohydrates, crude protein, ether extract, and neutral detergent fiber. The nutrient digestibility coefficient (CD) was determined according to the equation: 
$\mathrm{CD}=((\mathrm{kg}$ of ingested portion $-\mathrm{kg}$ of excreted portion $) /(\mathrm{kg}$ of ingested portion $)) \times 100$

The nitrogen balance and microbial protein production were evaluated by total urine collection. Total urine collection was carried out in individual bowls containing $50 \mathrm{~mL}$ of $20 \%$ sulfuric acid solution. The volume and $\mathrm{pH}$ were measured daily, and $10 \%$ of the total volume was stored to compose a pooled sample at the end of the collection period.

A $10 \mathrm{~mL}$ aliquot of the pooled urine sample was diluted in $40 \mathrm{~mL}$ of $0.036 \mathrm{~N}$ sulfuric acid $\left(\mathrm{H}_{2} \mathrm{SO}_{4}\right)$ solution and frozen at $-20{ }^{\circ} \mathrm{C}$ for further analysis of nitrogen compound excretion and purine derivatives, allantoin, uric acid, xanthine, and hypoxanthine to calculate the efficiency of microbial protein synthesis and the intestinal flow of nitrogen compounds, respectively. The nitrogen balance was determined by the difference between the amount ingested and the losses recorded in urine and feces.

The total urinary nitrogen content was determined according to the Kjeldhal method [25], and the nitrogen balance (NB) was obtained using the following equations and expressed in $\mathrm{g} /$ day and in $\mathrm{g} / \mathrm{kg}^{0.75} /$ day:

$$
\begin{gathered}
\mathrm{NB}=\mathrm{N}_{\text {ingested }}-\left(\mathrm{N}_{\text {feces }}+\mathrm{N}_{\text {urine }}\right) \\
\mathrm{N}_{\text {absorbed }}=\mathrm{N}_{\text {ingested }}-\mathrm{N}_{\text {feces }} \\
\mathrm{N}_{\text {ingested }}=\mathrm{N}_{\text {offered }}-\mathrm{N}_{\text {orts }}
\end{gathered}
$$

Allantoin, xanthine, hypoxanthine, and uric acid were determined according to Chen and Gomes [26] by calculating microbial purines absorbed from the excretion of purine derivatives in urine. The intestinal flux of microbial nitrogenous compounds $(\mathrm{N})$ was calculated as a function of microbial purines absorbed [26].

The ingestive behavior of the animals was evaluated during a $24 \mathrm{~h}$ period with observations every five minutes according to Martin and Bateson [27] by evaluating each animal individually in relation to the time spent on rumination, feeding, and idle activities. Chewing parameters were evaluated in each animal individually [28] in the morning (10:00), afternoon (15:00) and evening (21:00) by observing the number of chewing movements per bolus feeding, which was performed by previously trained evaluators using digital chronometers and artificial lighting at night, with previous adaptation of the animals. Feeding and rumination efficiencies based on DM and NDF were obtained by calculations described by Bürger et al. [29].

\subsection{Trial 3-Ruminal Fermentation Parameters Evaluation}

The ruminal fermentation parameters were evaluated using five Santa Inês sheep $(52.1 \pm 13.2 \mathrm{~kg} \mathrm{BW})$, cannulated in the rumen and housed individually in suspended stalls with feed and water troughs distributed in $5 \times 5$ Latin squares. The experiment had a duration of 55 days divided into periods of 11 days, with 10 days for adaptation to the diets and 1 day for data collection. Ruminal fluid samples (i.e., $100 \mathrm{~mL}$ ) were collected in the morning at 0 (before feeding), 2, 4 and $6 \mathrm{~h}$ after feeding, and the $\mathrm{pH}$ of the ruminal fluid was measured immediately after collection using a digital potentiometer.

To determine the ammoniacal nitrogen $\left(\mathrm{N}-\mathrm{NH}_{3}\right)$ concentration, samples of approximately $25 \mathrm{~mL}$ of rumen fluid were filtered through cheesecloth, placed in a recipient containing $1 \mathrm{~mL}$ of $1: 1$ sulfuric acid solution and stored at $-10{ }^{\circ} \mathrm{C}$ for later analysis. After thawing, the samples were distilled with $2 \mathrm{~N} \mathrm{KOH}$ solution, following the procedures of Detmann et al. [25] for total nitrogen determination. A $50 \mathrm{~mL}$ aliquot of ruminal fluid was mixed $(1: 1, v / v)$ with a $50 \%$ formalin solution for subsequent counting of the total number of protozoa, according to the method described by Dehority and Tirabasso [30]. 


\subsection{Statistical Analysis}

The variables of nutrient intake and digestibility, nitrogen balance, and ingestive behavior were analyzed by means of PROC MIXED SAS ${ }^{\circledR} 9.4$ software in an entirely randomized design, using the following mathematical model:

$$
Y_{i}=\mu+T_{i}+\varepsilon_{i}
$$

where $\mu$ is the overall mean, $T_{i}$ is the treatment effect, which is the fixed effect, and $\varepsilon_{i}$ is the experimental error.

Heterogeneity of variances was tested by the REPEATED command and used when significant; however, the variance was not homogeneous and was therefore not considered in the final data analysis. The covariance structures "diagonal, autoregressive, unstructured, and variance compounds" were tested and defined according to the lowest value obtained for the corrected Akaike information criterion corrected (cAIC). Polynomial contrasts were used to test the linear and quadratic effects of palm kernel oil supply in the lambs' diet on all parameters evaluated, selecting the contrast that best represents the data by the lowest value of the root mean square error (RMSE). Cubic effects were not used because there is no biological interpretation for these parameters. Initial body weight was tested as a covariate and used when significant.

For the variables of ruminal fermentation parameters (third trial), PROC MIXED was used for a Latin square design considering period and animal as random effects according to the following mathematical models; the first model was used for protozoa counts and the second for variables analyzed over time, such as $\mathrm{pH}$ and the ammoniacal nitrogen concentration in ruminal fluid:

$$
\begin{gathered}
\mathrm{Y}_{\mathrm{ijk}}=\mu+\mathrm{D}_{\mathrm{i}}+\mathrm{a}_{\mathrm{j}}+\mathrm{p}_{\mathrm{k}}+\varepsilon_{\mathrm{ijk}} \\
\mathrm{Y}_{\mathrm{ijkl}}=\mu+\mathrm{D}_{\mathrm{i}}+\mathrm{a}_{\mathrm{j}}+\mathrm{p}_{\mathrm{k}}+(\mathrm{D} \times \mathrm{a} \times \mathrm{p})+\mathrm{T}_{1}+(\mathrm{D} \times \mathrm{T})+\varepsilon_{\mathrm{ijk} \mathrm{l}}
\end{gathered}
$$

where $\mu$ corresponds to the overall mean, $D_{i}$ is the diet, which is a fixed effect, $a_{j}$ corresponds to the animal, $\mathrm{p}_{\mathrm{k}}$ is the period effect, which was considered a random effect, along with the animal effect; $\mathrm{T}_{1}$ corresponds to time, with was a fixed effect; and $\varepsilon_{\mathrm{ijkl}}$ is the experimental error.

The $\mathrm{pH}$ and ammoniacal nitrogen variables were evaluated as repeated measures over time using the cAIC value with the REPEATED command to choose the best error matrix structure. Degrees of freedom were adjusted according to Kenward-Roger by evaluating the effect of time using orthogonal contrasts.

The PROC NLIN command was used to analyze the observed linear plateau response for variables related to nitrogen balance using the lowest RMSE value among linear, quadratic, and linear plateau responses as the selection criterion. In addition, the mean of variables analysed were compared by Tukey's test (SAS ${ }^{\circledR}$ 9.4). A significant effect was declared when $p \leq 0.05$, and a trend was declared when $0.05<p \leq 0.10$.

\section{Results}

Reductions in DM $(p<0.001)$, ash $(p<0.001)$, CP $(p<0.001)$, NDF $(p<0.001)$, NFC $(p<0.001)$, and TDN $(p<0.001)$ intake with increasing PKO in the lambs' diet were observed (Table 2). Furthermore, an effect on body and metabolic weights was identified, with reduced intakes of DM $(p<0.001), \mathrm{CP}(p<0.001), \mathrm{NDF}(p<0.001)$, and TDN $(p<0.001)$ as the level of PKO inclusion increased. EE intake in g/day $(p<0.001), \mathrm{BW}(p=0.029)$, and metabolic weight $(p=0.007)$ showed a quadratic effect, with higher intake levels of EE and higher BW when the inclusion level of PKO was $2.47 \%$. The effectively ingested $\mathrm{CP}$ was not affected by the presence of $\mathrm{PKO}$ in the lambs' diet. A tendency for a linear reduction in effectively ingested NDF with increasing levels of palm kernel oil inclusion was identified. PKO addition to the diet caused reductions in the effective ingestion of ash $(p=0.020)$, NFC $(p=0.002)$, and TDN $(p<0.001)$ (Table 2$)$. The effectively ingested EE showed a quadratic 
effect, with higher consumption as the inclusion level of PKO increased. The digestibility of NDF was not influenced by the presence of PKO in the diet of finishing lambs. A trend toward a quadratic effect of PKO on the digestibility coefficient of NFC $(p=0.071)$ was found (Table 2). Linear increases in the digestibility coefficients of DM $(p=0.035), \mathrm{CP}$ $(p<0.001)$, and TDN $(p<0.001)$ were also noted. A quadratic effect of the addition of PKO on the digestibility coefficient of the EE was further identified, with higher digestibility when the inclusion level was 5.2\% PKO.

Table 2. Nutrient intake (g/day; $\mathrm{g} / \mathrm{kg} \mathrm{BW} ; \mathrm{g} / \mathrm{kg} \mathrm{BW}^{0.75}$ ) and digestibility coefficient of finishing lambs fed diets containing palm kernel oil (PKO).

\begin{tabular}{|c|c|c|c|c|c|c|c|c|c|}
\hline \multirow{2}{*}{ Item } & \multicolumn{5}{|c|}{ Palm Kernel Oil Levels (\%DM Dietary Total) } & \multirow{2}{*}{ SEM $^{1}$} & \multicolumn{3}{|c|}{$p$-Value ${ }^{2}$} \\
\hline & 0 & 1.3 & 2.6 & 3.9 & 5.2 & & $\mathbf{L}$ & $\mathbf{Q}$ & Effect \\
\hline \multicolumn{10}{|c|}{ Nutrient Intake (g/day) } \\
\hline Dry matter & $1113.0^{\mathrm{a}}$ & $1092.3^{\mathrm{a}}$ & $861.6^{\mathrm{b}}$ & $816.9^{b}$ & $673.1^{\mathrm{c}}$ & 37.6 & $<0.01$ & 0.68 & $<0.01$ \\
\hline Ash & $68.0^{\mathrm{a}}$ & $65.9^{\mathrm{a}}$ & $50.9^{b}$ & $48.2^{\mathrm{b}}$ & $39.7^{c}$ & 2.31 & $<0.01$ & 0.94 & $<0.01$ \\
\hline Crude protein & $166.2^{\mathrm{a}}$ & $161.1^{\mathrm{a}}$ & $129.6^{\mathrm{b}}$ & $115.2^{b c}$ & $97.9^{\mathrm{c}}$ & 5.43 & $<0.01$ & 0.73 & $<0.01$ \\
\hline Ether extract & $17.1^{\mathrm{d}}$ & $32.1^{\mathrm{c}}$ & $38.7^{\mathrm{b}}$ & $49.4^{\mathrm{a}}$ & $54.4^{\mathrm{a}}$ & 1.14 & $<0.01$ & $<0.01$ & $<0.01$ \\
\hline $\mathrm{NDF}_{\mathrm{ap}}{ }^{3}$ & $345.4^{\mathrm{a}}$ & $344.1^{\mathrm{a}}$ & $258.1^{\mathrm{b}}$ & $261.0^{\mathrm{b}}$ & $187.5^{\mathrm{c}}$ & 16.8 & $<0.01$ & 0.39 & $<0.01$ \\
\hline $\mathrm{NFC}^{4}$ & $516.3^{\mathrm{a}}$ & $489.2^{\mathrm{a}}$ & $384.3^{b}$ & $343.1^{b c}$ & $293.3^{c}$ & 14.5 & $<0.01$ & 0.74 & $<0.01$ \\
\hline $\mathrm{TDN}^{5}$ & $755.5^{\mathrm{a}}$ & $808.9^{a}$ & $654.7^{\mathrm{b}}$ & $623.7^{b c}$ & $616.7^{\mathrm{c}}$ & 35.6 & 0.02 & 0.99 & 0.02 \\
\hline \multicolumn{10}{|c|}{ Nutrient Intake as Body Weight (g/kg BW) } \\
\hline Dry matter & $34.0^{\mathrm{a}}$ & $31.9^{\mathrm{a}}$ & $27.2^{b}$ & $25.8^{\mathrm{b}}$ & $20.5^{c}$ & 0.93 & $<0.01$ & 0.32 & $<0.01$ \\
\hline Crude protein & $5.09^{a}$ & $4.72^{\mathrm{a}}$ & $4.10^{\mathrm{b}}$ & $3.65^{b}$ & $2.93^{c}$ & 0.14 & $<0.01$ & 0.37 & $<0.01$ \\
\hline Ether extract & $0.52^{\mathrm{e}}$ & $0.94^{\mathrm{d}}$ & $1.21^{\mathrm{c}}$ & $1.55^{\mathrm{b}}$ & $1.76^{\mathrm{a}}$ & 0.04 & $<0.01$ & 0.03 & $<0.01$ \\
\hline $\mathrm{NDF}_{\mathrm{ap}}$ & $10.5^{\mathrm{a}}$ & $10.0^{\mathrm{ab}}$ & $8.09 \mathrm{bc}$ & $8.23^{c}$ & $5.75^{d}$ & 0.46 & $<0.01$ & 0.18 & $<0.01$ \\
\hline NFC & $15.8^{a}$ & $14.3^{\mathrm{b}}$ & $12.2^{\mathrm{c}}$ & $10.9^{c}$ & $8.89^{d}$ & 0.37 & $<0.01$ & 0.95 & $<0.01$ \\
\hline TDN & $20.9^{a}$ & $21.7^{\mathrm{a}}$ & $17.3^{\mathrm{b}}$ & $16.8^{\mathrm{b}}$ & $14.5^{\mathrm{c}}$ & 1.28 & $<0.01$ & 0.65 & $<0.01$ \\
\hline \multicolumn{10}{|c|}{ Nutrient Intake by Body Weight (g/kg BW $\left.{ }^{0.75}\right)$} \\
\hline Dry matter & $81.3^{\mathrm{a}}$ & $77.2^{\mathrm{a}}$ & $64.4^{\mathrm{b}}$ & $61.2^{\mathrm{b}}$ & $48.9^{\mathrm{c}}$ & 2.29 & $<0.01$ & 0.40 & $<0.01$ \\
\hline Crude Protein & $12.1^{\mathrm{a}}$ & $11.4^{\mathrm{a}}$ & $9.71^{\mathrm{b}}$ & $8.64^{\mathrm{b}}$ & $7.03^{c}$ & 0.34 & $<0.01$ & 0.45 & $<0.01$ \\
\hline Ether Extract & $1.24 \mathrm{e}$ & $2.26^{\mathrm{d}}$ & $2.88^{\mathrm{c}}$ & $3.68^{b}$ & $4.16^{\mathrm{a}}$ & 0.08 & $<0.01$ & $<0.01$ & $<0.01$ \\
\hline $\mathrm{NDF}_{\mathrm{ap}}{ }^{3}$ & $25.1^{\mathrm{a}}$ & $24.3^{\mathrm{a}}$ & $19.3^{\mathrm{b}}$ & $19.6^{\mathrm{b}}$ & $13.5^{\mathrm{c}}$ & 1.12 & $<0.01$ & 0.22 & $<0.01$ \\
\hline $\mathrm{NFC}^{4}$ & $37.8^{\mathrm{a}}$ & $34.6^{\mathrm{a}}$ & $28.8^{\mathrm{b}}$ & $25.8^{\mathrm{b}}$ & $21.3^{c}$ & 0.89 & $<0.01$ & 0.96 & $<0.01$ \\
\hline $\mathrm{TDN}^{5}$ & $51.3^{\mathrm{a}}$ & $53.6^{\mathrm{a}}$ & $42.9^{b}$ & $41.5^{\mathrm{b}}$ & $36.0^{c}$ & 3.18 & $<0.01$ & 0.60 & $<0.01$ \\
\hline \multicolumn{10}{|c|}{ Effective Nutrient Intake (g/100g) } \\
\hline Ash & 6.11 & 6.03 & 5.92 & 5.89 & 5.88 & 0.08 & 0.02 & 0.52 & 0.17 \\
\hline Crude protein & 14.9 & 14.8 & 15.1 & 14.1 & 14.4 & 0.38 & 0.20 & 0.93 & 0.36 \\
\hline Ether extract & $1.53^{\mathrm{e}}$ & $2.94^{\mathrm{d}}$ & $4.48^{\mathrm{c}}$ & $6.02^{b}$ & $8.53^{\mathrm{a}}$ & 0.09 & $<0.01$ & $<0.01$ & $<0.01$ \\
\hline $\mathrm{NDF}_{\mathrm{ap}}{ }^{3}$ & 30.8 & 31.4 & 29.8 & 31.9 & 27.2 & 1.22 & 0.09 & 0.16 & 0.06 \\
\hline $\mathrm{NFC}^{4}$ & $46.6^{\mathrm{a}}$ & $44.8^{\mathrm{ab}}$ & $44.6^{\mathrm{ab}}$ & $42.0^{\mathrm{b}}$ & $44.0^{\mathrm{ab}}$ & 0.78 & $<0.01$ & 0.14 & $<0.01$ \\
\hline $\mathrm{TDN}^{5}$ & $67.3^{c}$ & $71.7^{b c}$ & $76.1^{\mathrm{ab}}$ & $79.1^{\mathrm{ab}}$ & $78.7^{\mathrm{a}}$ & 1.68 & $<0.01$ & 0.10 & $<0.01$ \\
\hline \multicolumn{10}{|c|}{ Nutrient Digestibility Coefficient (\%) } \\
\hline Dry matter & 68.9 & 72.3 & 74.5 & 75.5 & 74.1 & 1.78 & 0.04 & 0.13 & 0.28 \\
\hline Crude Protein & $69.8^{b}$ & $74.3^{a b}$ & $77.6^{\mathrm{a}}$ & $79.6^{\mathrm{a}}$ & $78.3^{a}$ & 1.60 & $<0.01$ & 0.05 & 0.30 \\
\hline Ether Extract & $63.4^{\mathrm{d}}$ & $81.2^{\mathrm{c}}$ & $88.4^{\mathrm{b}}$ & $94.1^{\mathrm{a}}$ & $94.2^{\mathrm{a}}$ & 1.12 & $<0.01$ & $<0.01$ & $<0.01$ \\
\hline $\mathrm{NDF}_{\mathrm{ap}}{ }^{3}$ & 40.6 & 47.2 & 47.1 & 51.7 & 42.2 & 4.03 & 0.21 & 0.26 & 0.45 \\
\hline $\mathrm{NFC}^{4}$ & 88.8 & 89.8 & 90.4 & 89.7 & 88.0 & 0.73 & 0.65 & 0.07 & 0.33 \\
\hline $\mathrm{TDN}^{5}$ & $67.3^{c}$ & $71.7^{b c}$ & $76.1^{\mathrm{ab}}$ & $79.1^{a b}$ & $76.7^{\mathrm{a}}$ & 1.67 & $<0.01$ & 0.10 & $<0.01$ \\
\hline
\end{tabular}

${ }^{1}$ Standard error of the mean. ${ }^{2}$ Significance at $p<0.05$ and trend between $p \leq 0.05$ and $p \leq 0.10$; L, linear Q, quadratic. ${ }^{3}$ Neutral detergent fiber corrected for ash and protein. ${ }^{4}$ Nonfibrous carbohydrates. ${ }^{5}$ Total digestible nutrients. ${ }^{\text {a-e }}$ Means followed by different letters differ by Tukey's test $(p<0.05)$.

From the means test, the intake of lambs ( $\left.\mathrm{g} / \mathrm{d} ; \mathrm{g} / \mathrm{kg} \mathrm{BW} ; \mathrm{g} / \mathrm{kg} \mathrm{BW}^{0.75}\right)$, along with $\mathrm{DM}$, ash, $\mathrm{CP}, \mathrm{NDF}_{\text {ap }} \mathrm{NFC}$, and TDN intake, were higher $(p<0.05)$ with $0 \%$ and $1.3 \%$ of PKO inclusion (as DM total dietary) when compared to the other inclusion levels evaluated. In contrast, the control treatment $(0 \%)$ promoted a lower $(p<0.05)$ EE intake $(\mathrm{g} / \mathrm{d} ; \mathrm{g} / \mathrm{kg} \mathrm{BW}$; $\mathrm{g} / \mathrm{kg} \mathrm{BW}^{0.75}$ ) in lamb, followed 1.3\%; 2.6\% PKO. On other hand, the inclusion of 3.9 and 
$5.2 \%$ of PKO had the highest EE intake. With regard to nutrient digestibility, the inclusion of $0 \%$ presented lower $\mathrm{CP}$ digestibility compared to other treatments.

The final weight $(p=0.061)$, total weight gain $(p=0.058)$ and average daily gain ( $p=0.057$ ) showed a linear decreasing trend as the level of PKO in the diet increased, as well as a linear decreasing effect for feed conversion, with better feed conversion for animals fed diets containing the highest level of PKO ( $p=0.001$; Table 3). Also, 3.9 PKO inclusion was associated with lower $(p<0.05)$ total weight gain and ADG compared to other treatments, while the inclusion of $5.2 \%$ PKO was associated with the best feed conversion $(p<0.05)$.

Table 3. Performance of finishing lambs fed diets containing palm kernel oil (PKO).

\begin{tabular}{|c|c|c|c|c|c|c|c|c|c|}
\hline \multirow{2}{*}{ Item } & \multicolumn{5}{|c|}{ Palm Kernel Oil Levels (\%DM Dietary Total) } & \multirow{2}{*}{ SEM $^{1}$} & \multicolumn{3}{|c|}{$p$-Value ${ }^{2}$} \\
\hline & 0 & 1.3 & 2.6 & 3.9 & 5.2 & & $\mathbf{L}$ & $\mathbf{Q}$ & Effect \\
\hline Initial body weight (kg) & 25.10 & 26.85 & 26.40 & 26.48 & 23.83 & - & - & - & \\
\hline Final body weight $(\mathrm{kg})$ & 40.12 & 42.68 & 37.94 & 37.44 & 39.02 & 1.22 & 0.06 & 0.63 & 0.13 \\
\hline Total weight gain $(\mathrm{kg})$ & $14.40^{\mathrm{ab}}$ & $16.92^{\mathrm{a}}$ & $12.20^{\mathrm{ab}}$ & $11.70^{\mathrm{b}}$ & $13.32^{a b}$ & 1.19 & 0.06 & 0.59 & 0.03 \\
\hline Average daily gain (kg) & $0.18^{a b}$ & $0.21^{\mathrm{a}}$ & $0.15^{\mathrm{ab}}$ & $0.14^{\mathrm{b}}$ & $0.16^{\mathrm{ab}}$ & 0.01 & 0.06 & 0.59 & 0.03 \\
\hline Feed conversion $(\mathrm{kg} / \mathrm{kg})$ & $6.91^{\mathrm{a}}$ & $5.39 \mathrm{ab}$ & $6.40^{\mathrm{a}}$ & $5.73^{a b}$ & $4.05^{b}$ & 0.51 & $<0.01$ & 0.45 & 0.02 \\
\hline
\end{tabular}

${ }^{1}$ Standard error of the mean. ${ }^{2}$ Significance at $p<0.05$ and trend between $p \leq 0.05$ and $p \leq 0.10$; L, linear; $\mathrm{Q}$, quadratic. ${ }^{\mathrm{a}, \mathrm{b}}$ Means followed by different letters differ by Tukey's test $(p<0.05)$.

PKO addition to the diet reduced the $\mathrm{N}$ retained by lambs until the inclusion level of $2.62 \%$ of this fatty acid in the lambs' diet $(\forall \mathrm{x} \leq 2.62 \mathrm{Y}=6.380 ; \forall \mathrm{x}>2.62$ $\mathrm{Y}=6.38+1.7546 \times(2.6272-\mathrm{X}) ; \mathrm{RMSE}=3.963)$, with stabilization in its values as the concentration of PKO increased until the inclusion level of 5.2\% (Table 4). No effect of PKO on the microbial protein production efficiency of lambs was found. As the level of PKO supply in the diet increased, reductions in N intake $(p<0.001)$, fecal N excretion $(p<0.001)$, and microbial protein production $(p<0.001)$ occurred. There was a quadratic effect for urinary $\mathrm{N}$ excretion $(p=0.048)$, with higher urinary $\mathrm{N}$ excretion when the inclusion level of PKO in the diet was 5.2\%. In means test comparisons, $\mathrm{N}$ intake and microbial protein production (g/day) was similarly high for 0 (control), 1.3\%, and 2.6 PKO inclusion (as DM total dietary) compared to 3.9 and 5.2\% PKO inclusion in the lambs' diet, and the inclusion of $5.2 \%$ PKO was associated with a lower intake. $\mathrm{N}$ fecal excretion was greater $(p<0.05)$ for groups 0 (control) and 1.3\% PKO inclusion compared to 2.6, 3.9\%, and 5.2\% PKO inclusion in the lambs' diet, which were associated with similar $\mathrm{N}$ fecal excretion values.

PKO inclusion in the lambs' diet linearly increased the serum cholesterol concentration $(p<0.001)$. In contrast, a linear decrease in gamma-glutamyltransferase (GGT) enzyme blood concentration $(p=0.048)$ due to PKO addition in the lambs' diet was observed. Serum concentrations of total proteins $(p=0.860)$, albumins $(p=0.574)$, globulins $(p=0.736)$, and triglycerides ( $p=0.144)$, and the ratio between albumins and globulins $(p=0.593)$, as well as the enzymatic concentrations of aspartate aminotransferase $(p=0.308)$ and alanine aminotransferase $(p=0.230)$, were not affected by increasing levels of PKO in the lambs' $\operatorname{diet}$ (Table 4).

The means test demonstrated that no PKO inclusion was associated with lower $(p<0.05)$ cholesterol $(\mathrm{mg} / \mathrm{dL})$ compared to other treatments. In contrast, the inclusion of $5.2 \%$ of $\mathrm{PKO}$ in the lambs' diet promoted the lower ruminal protozoa count compared to other treatments.

A decrease in ruminal fluid $\mathrm{pH}$ values over time was noted after feed intake $(p<0.001$; Figure 1). PKO inclusion in the lambs' diet did not affect the $\mathrm{pH}$ of the ruminal fluid of lambs or the ammoniacal nitrogen concentration. However, PKO addition to the diet reduced the total protozoa count $(p=0.002)$ of the ruminal fluid of lambs linearly (Table 4 ). 
Table 4. Nitrogen balance, production and efficiency of microbial protein production, and blood and ruminal parameters of finishing lambs fed diets containing palm kernel oil (PKO).

\begin{tabular}{|c|c|c|c|c|c|c|c|c|c|}
\hline \multirow{2}{*}{ Item } & \multicolumn{5}{|c|}{ Palm Kernel Oil Levels (\%DM Dietary Total) } & \multirow{2}{*}{ SEM $^{1}$} & \multicolumn{3}{|c|}{$p$-Value ${ }^{2}$} \\
\hline & 0 & 1.3 & 2.6 & 3.9 & 5.2 & & $\mathbf{L}$ & $\mathbf{Q}$ & Effect \\
\hline \multicolumn{10}{|c|}{ Nitrogen Balance (g/day) } \\
\hline $\mathrm{N}$ intake & $26.8^{a}$ & $27.0^{\mathrm{a}}$ & $21.4^{\mathrm{ab}}$ & $18.3^{b}$ & $18.2^{\mathrm{b}}$ & 1.10 & $<0.01$ & 0.73 & $<0.01$ \\
\hline $\mathrm{N}$ fecal & $8.01^{\mathrm{a}}$ & $6.93^{\mathrm{a}}$ & $4.83^{b}$ & $3.73^{b}$ & $3.67^{b}$ & 0.45 & $<0.01$ & 0.09 & $<0.01$ \\
\hline $\mathrm{N}$ urinary & 8.55 & 9.99 & 10.9 & 8.46 & 7.64 & 0.99 & 0.30 & 0.04 & 0.18 \\
\hline $\mathrm{N}$ retained & 10.3 & 10.1 & 5.72 & 6.07 & 6.77 & 1.86 & 0.08 & 0.37 & 0.24 \\
\hline \multicolumn{10}{|c|}{ Microbial Protein (g/day) } \\
\hline Production & $38.0^{\mathrm{a}}$ & $33.5^{\mathrm{ab}}$ & $28.1^{\mathrm{abc}}$ & $23.9^{b c}$ & $19.8^{c}$ & 2.83 & $<0.01$ & 0.56 & $<0.01$ \\
\hline Efficiency & 45.5 & 41.5 & 43.3 & 38.6 & 37.2 & 3.97 & 0.14 & 0.93 & 0.23 \\
\hline \multicolumn{10}{|c|}{ Blood Parameters } \\
\hline Proteins (g/dL) & 7.60 & 7.59 & 7.91 & 7.48 & 7.61 & 0.16 & 0.86 & 0.96 & 0.92 \\
\hline Albumins (mg/dL) & 3.43 & 3.91 & 3.45 & 3.37 & 3.53 & 0.18 & 0.57 & 0.71 & 0.28 \\
\hline Globulins (mg/dL) & 4.17 & 3.68 & 4.24 & 4.11 & 4.08 & 0.24 & 0.74 & 0.79 & 0.51 \\
\hline A:G Ratio ${ }^{3}$ & 0.83 & 1.14 & 0.91 & 0.84 & 0.88 & 0.12 & 0.59 & 0.40 & 0.35 \\
\hline Cholesterol (mg/dL) & $53.7^{\mathrm{b}}$ & $72.7^{a b}$ & $91.5^{\mathrm{a}}$ & $80.7^{\mathrm{ab}}$ & $91.5^{\mathrm{a}}$ & 7.18 & $<0.01$ & 0.10 & $<0.01$ \\
\hline Triglycerides (mg/dL) & 15.2 & 13.2 & 15.7 & 17.4 & 17.9 & 2.02 & 0.14 & 0.58 & 0.49 \\
\hline $\mathrm{GGT}^{4}(\mathrm{UI} / \mathrm{L})$ & 49.2 & 52.2 & 44.7 & 45.5 & 44.4 & 2.49 & 0.04 & 0.99 & 0.15 \\
\hline $\mathrm{AST}^{5}(\mathrm{UI} / \mathrm{L})$ & 79.0 & 66.2 & 84.2 & 85.3 & 76.2 & 7.52 & 0.31 & 0.47 & 0.09 \\
\hline $\operatorname{ALT}^{6}(\mathrm{UI} / \mathrm{L})$ & 12.4 & 11.5 & 15.3 & 14.8 & 14.4 & 2.07 & 0.23 & 0.23 & 0.31 \\
\hline \multicolumn{10}{|c|}{ Ruminal Parameters } \\
\hline $\mathrm{pH}$ & 6.10 & 5.99 & 5.93 & 6.08 & 6.16 & 0.11 & 0.57 & 0.16 & 0.46 \\
\hline $\mathrm{N}-\mathrm{NH}_{3}$ & 18.7 & 17.5 & 19.0 & 17.1 & 19.2 & 1.89 & 0.85 & 0.75 & 0.93 \\
\hline Protozoa $\left(\times 10^{6} \mathrm{~mL}^{-1}\right)$ & $8.87^{b}$ & $14.3^{\mathrm{a}}$ & $4.52^{\mathrm{c}}$ & $3.00^{d}$ & $0.72^{\mathrm{e}}$ & 1.47 & $<0.01$ & 0.38 & $<0.01$ \\
\hline
\end{tabular}

${ }^{1}$ Standard error of the mean. ${ }^{2}$ Significance at $p<0.05$ and trend between $p<0.05$ and $p<0.10$; L, linear; Q, quadratic. ${ }^{3}$ Albumin: Globulin ratio. ${ }^{4}$ Gamma-glutamyl transferase enzyme. ${ }^{5}$ Aspartate-aminotransferase enzyme; ${ }^{6}$ Alanine-aminotransferase enzyme. ${ }^{\text {a-e }}$ Means followed by different letters differ by Tukey's test $(p<0.05)$.

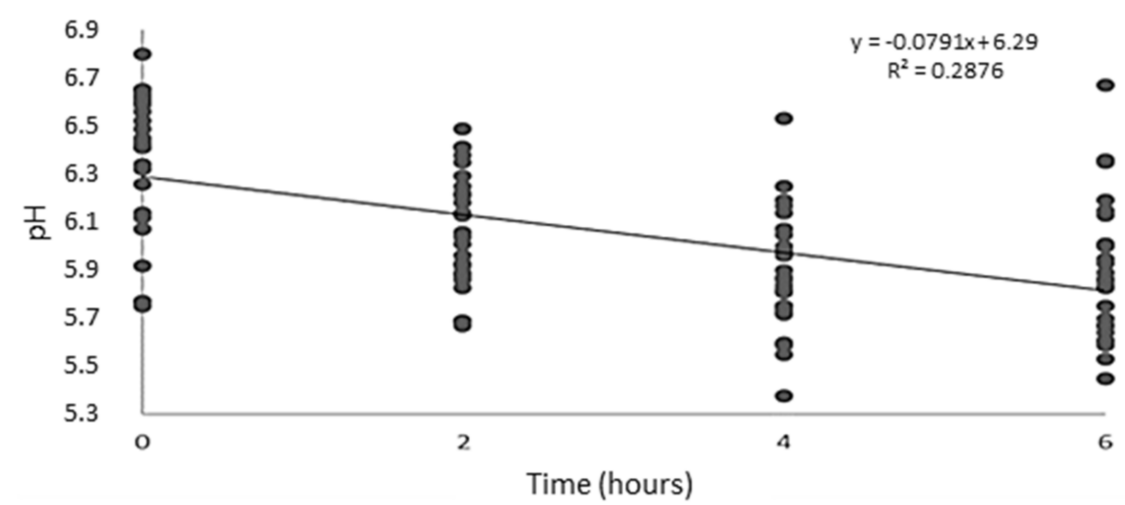

Figure 1. Effect of feeding time on ruminal fluid $\mathrm{pH}$ of lambs fed diets containing palm kernel oil.

The addition of PKO to the lambs' diet did not affect the time spent ruminating $(p=0.72)$ or idling $(p=0.84$; Table 5). A linear increasing trend was observed for time spent feeding $(p=0.078)$ and number of chews per bolus $(p=0.066)$. The feeding efficiency of $\operatorname{DM}(p=0.008)$ and NDF $(p=0.018)$, as well as the rumination efficiency of DM $(p<0.001)$ and NDF $(p<0.001)$, decreased linearly with the inclusion of PKO in the lambs' diet. 
Table 5. Ingestive behavior of finishing lambs fed diets containing palm kernel oil (PKO).

\begin{tabular}{|c|c|c|c|c|c|c|c|c|c|}
\hline \multirow{2}{*}{ Item } & \multicolumn{5}{|c|}{ Palm Kernel Oil Levels (\%DM Dietary Total) } & \multirow{2}{*}{ SEM $^{1}$} & \multicolumn{3}{|c|}{$p$-Value ${ }^{2}$} \\
\hline & 0 & 1.3 & 2.6 & 3.9 & 5.2 & & $\mathbf{L}$ & Q & Effect \\
\hline \multicolumn{10}{|c|}{ Intake (g/d) } \\
\hline Dry matter & $1117.1^{\mathrm{a}}$ & $1127.9^{\mathrm{a}}$ & $863.5^{a b}$ & $789.5^{\mathrm{b}}$ & $692.4^{\mathrm{b}}$ & 65.5 & $<0.01$ & 0.92 & $<0.01$ \\
\hline NDF & $324.9^{\mathrm{a}}$ & $371.1^{\mathrm{a}}$ & $259.5^{a b}$ & $254.4^{\mathrm{ab}}$ & $209.5^{b}$ & 23.5 & $<0.01$ & 0.40 & $<0.01$ \\
\hline \multicolumn{10}{|c|}{ Ingestive Behavior (min/day) } \\
\hline Feed & 208 & 183 & 219 & 270 & 230 & 21.7 & 0.08 & 0.86 & 0.19 \\
\hline Rumination & 475 & 461 & 533 & 483 & 446 & 31.8 & 0.72 & 0.17 & 0.40 \\
\hline Idleness & 757 & 796 & 688 & 687 & 798 & 42.2 & 0.84 & 0.13 & 0.22 \\
\hline \multicolumn{10}{|c|}{ Chewing (Frequency or Number of Events) } \\
\hline No./bolus & 55.2 & 50.0 & 57.7 & 65.3 & 66.5 & 2.81 & 0.07 & 0.59 & 0.31 \\
\hline Seg/bolus & 41.4 & 38.9 & 46.1 & 47.9 & 43.8 & 1.69 & 0.28 & 0.56 & 0.43 \\
\hline \multicolumn{10}{|c|}{ Feed Efficiency (g/h) } \\
\hline Dry matter & $337.8^{a b}$ & $338.3^{\mathrm{a}}$ & $237.1^{a b}$ & $177.9^{\mathrm{b}}$ & $247.8^{a b}$ & 37.0 & $<0.01$ & 0.20 & 0.03 \\
\hline $\mathrm{NDF}$ & $112.0^{\mathrm{ab}}$ & $137.9^{\text {a }}$ & $71.1^{\mathrm{ab}}$ & $57.2^{b}$ & $73.4^{\mathrm{ab}}$ & 14.3 & 0.02 & 0.60 & 0.02 \\
\hline \multicolumn{10}{|c|}{ Rumination Efficiency (g/h) } \\
\hline Dry matter & $141.7^{\mathrm{a}}$ & $148.2^{\mathrm{a}}$ & $98.3^{\mathrm{b}}$ & $99.8^{\mathrm{b}}$ & $92.6^{\mathrm{b}}$ & 8.57 & $<0.01$ & 0.46 & $<0.01$ \\
\hline NDF & $45.4^{\mathrm{a}}$ & $48.8^{\mathrm{a}}$ & $29.2^{b}$ & $32.1^{b}$ & $27.7^{b}$ & 2.83 & $<0.01$ & 0.54 & $<0.01$ \\
\hline
\end{tabular}

${ }^{1}$ Standard error of the mean. ${ }^{2}$ Significance at $p<0.05$ and trend between $p \leq 0.05$ and $p \leq 0.10$; L, linear; $\mathrm{Q}$, quadratic. ${ }^{\mathrm{a}, \mathrm{b}}$ Means followed by different letters differ by Tukey's test $(p<0.05)$.

From the means test, it was observed that feed efficiency $(\mathrm{g} / \mathrm{h})$ of DM and NDF was similarly high with 0 (control), 1.3, 2.6, and 5.2\% PKO inclusion (as DM total dietary) compared to 3.9 PKO inclusion in the lambs' diet. DM and NDF rumination efficiency was similarly high with 0 (control) and $1.3 \%$ PKO inclusion compared to other treatments.

\section{Discussion}

The DM intake reduction observed in the present study consequently reduced the intake of other nutrients (except for the ether extract) and the feeding (g DM/h) and rumination ( $\mathrm{g} \mathrm{DM} / \mathrm{h}$ and $\mathrm{g} \mathrm{NDF} / \mathrm{h}$ ) efficiencies as PKO inclusion increased. As a result, this lower intake consequently resulted in more time spent feeding, probably due to feed selection behavior and lower animal performance. PKO addition resulted in lower nutrient intake. Allen [31] suggested that this effect on intake may be related to the impact of fat on ruminal fermentation, the acceptability of diets, the release of gut hormones, such as cholecystokinin, that act on the satiety control center, and the effect of lipid oxidation in the liver. However, despite this low intake and lower performance, the inclusion of PKO in the diet indicated better utilization of the ingested feed according to the digestibility and feed conversion data. This is probably due to the higher energy density as the inclusion of oil increased. Furthermore, it is also interesting to note that this did not affect fiber digestibility, even with reduced intake. According to Palmquist and Jenkins [32], high lipidic levels in ruminant diets $(>70 \mathrm{~g} / \mathrm{kg} \mathrm{DM})$ can inhibit ruminal fermentation, negatively affect fiber digestibility and modify the microbial population $[1,33]$. However, we did not observe any effect on ruminal fermentation.

The fatty acids present in PKO (Supplementary Table S1) were related to the reduction in the protozoan population [34]. In our study, we evaluated only the ruminal protozoan population and observed that PKO addition in the diet of lambs up to the level of $5.2 \%$ dry matter caused a decrease in these microorganisms without causing effects on ruminal fermentation parameters, which may be related to the presence of lauric acid, as observed by $[8,15,35]$ and Matsumoto et al. [36], who reported the toxic effect of lauric acid on some ruminal microorganisms, especially protozoa [1]. Indeed, this effect can be explained by the fact lauric acid, a medium-chain fatty acid with characteristics similar to polyunsaturated fatty acids, can be adsorbed to the microbial surface and incorporated into the membrane, promoting changes in its permeability and fluidicity $[13,14,37]$, leading to membrane destabilization and potentially impairing microbial development. This corroborates our 
data, since we also observed lower microbial protein synthesis with the inclusion of palm kernel oil. However, the reduction of the protozoan population may be beneficial, since its presence in the ruminal environment is closely related to energy loss in the form of methane [38,39].

Despite the effect on microbial protein production, the efficiency of microbial protein production was not affected by the presence of this source of fatty acids in the diet of animals. The efficiency of microbial protein production is closely related to the amount of microbial protein that reaches the small intestine, and the increase in the nitrogenous compound concentration in serum and urine indicates a reduction in production efficiency [1,40]. Thus, even with reduced intake and decreased microbial protein production, microbial protein production efficiency remained unaffected due to increased nitrogen availability and decreased nitrogen losses in the ruminal environment. Under conditions of low $\mathrm{N}$ intake, more recycling of metabolized nitrogen in the form of urea occurs, which may lead to a decrease in $\mathrm{N}$ excretion due to higher utilization by the animal [41,42], as verified in the present study.

The inclusion of PKO affected only two blood metabolites evaluated. The plasma concentration of cholesterol increased with the increased inclusion of palm kernel oil in the diet. According to Mayes and Botham [43], the presence of saturated fatty acid sources, such as PKO, in the diet promotes the formation of smaller VLDL particles, which are used by the extrahepatic tissues more slowly when compared to larger particles, and the decrease in absorption rates by the tissues could increase circulating cholesterol, causing an increase in serum concentrations of this component. The GGT serum concentration was reduced by the presence of palm kernel oil, and this enzyme is normally associated with liver status, being particularly linked to long-term liver injury [44]. Most likely, this increased dietary lipid content can have positive effects on the liver of lambs; however, all the mean values observed are within the range considered normal $[45,46]$.

\section{Conclusions}

The inclusion of $1.3 \%$ palm kernel oil (PKO) in a lamb diet was associated with intake, digestibility, ingestive behavior, and growth performance in lambs similar to animals that did not receive PKO. In contrast, the inclusion of 5.2\% of PKO in total DM dietary reduced intake, despite increasing digestibility and feed conversion and reducing fecal nitrogen excretion. Thus, PKO, up to $1.3 \%$ DM total, can be an alternative energy source for growing lambs. It is important to note that the use of this byproduct is recommended when it is easily available and cost-effective.

Supplementary Materials: The following are available online at https:/ / www.mdpi.com/article/10 .3390/ani12040427/s1, Table S1: Fatty acid composition of palm kernel oil.

Author Contributions: Conceptualization, D.P.V.C., A.M.B., E.S.P., C.V.D.M.R., L.R.B. and R.L.O.; methodology, A.M.B., J.M.d.S.J. and R.L.O.; validation, D.P.V.C., P.R.S.P. and J.M.d.S.J.; formal analysis, D.P.V.C., P.R.S.P., J.M.d.S.J., E.S.P. and C.V.D.M.R.; investigation, D.P.V.C. and P.R.S.P.; data curation, D.P.V.C. and J.M.d.S.J.; writing—original draft preparation, D.P.V.C., J.M.d.S.J., E.A.d.A. and G.F.V.J.; writing-review and editing, D.P.V.C., E.A.d.A. and G.F.V.J.; supervision, L.R.B. and R.L.O.; project administration, R.L.O.; funding acquisition, R.L.O. All authors have read and agreed to the published version of the manuscript.

Funding: This research was funded by the Bahia State Research Foundation (FAPESB), National Council for Scientific and Technological Development (CNPq-Brazil), and the Coordination for the Improvement of Higher Education Personnel (CAPES-Brazil).

Institutional Review Board Statement: All procedures were approved by the Ethics Committee in the Use of Animals of the School of Veterinary Medicine and Animal Science of the Federal University of Bahia (UFBA), protocol No. 40/2014.

Data Availability Statement: Data are not publicly available due to restrictions on the research group but can be requested from the corresponding author. 
Acknowledgments: The authors would like to acknowledge the continued support received from the Federal University of Bahia (UFBA).

Conflicts of Interest: The authors declare no conflict of interest.

\section{References}

1. Dai, X.; Faciola, A.P. Evaluating Strategies to Reduce Ruminal Protozoa and Their Impacts on Nutrient Utilization and Animal Performance in Ruminants-A Meta-Analysis. Front. Microbiol. 2019, 10, 2648. [CrossRef] [PubMed]

2. Newbold, C.J.; Ramos-Morales, E. Review: Ruminal microbiome and microbial metabolome: Effects of diet and ruminant host. Animal 2020, 14, s78-s86. [CrossRef] [PubMed]

3. Girón, J.E.P.; Restrepo, M.L.P.; Fornaguera, J.E.C. Supplementation with corn oil and palm kernel oil to grazing cows: Ruminal fermentation, milk yield, and fatty acid profile. Rev. Bras. Zootec. 2016, 45, 693-703. [CrossRef]

4. Do Prado, A.C.P.; Block, J.M. Palm and Palm Kernel Oil Production and Processing in Brazil. In Palm Oil; Elsevier: Amsterdam, The Netherlands, 2012; pp. 251-274.

5. Matsue, M.; Mori, Y.; Nagase, S.; Sugiyama, Y.; Hirano, R.; Ogai, K.; Ogura, K.; Kurihara, S.; Okamoto, S. Measuring the Antimicrobial Activity of Lauric Acid against Various Bacteria in Human Gut Microbiota Using a New Method. Cell Transpl. 2019, 28, 1528-1541. [CrossRef]

6. Nakatsuji, T.; Kao, M.C.; Fang, J.-Y.; Zouboulis, C.C.; Zhang, L.; Gallo, R.L.; Huang, C.-M. Antimicrobial Property of Lauric Acid Against Propionibacterium Acnes: Its Therapeutic Potential for Inflammatory Acne Vulgaris. J. Investig. Dermatol. 2009, 129, 2480-2488. [CrossRef]

7. Nitbani, F.O.; Jumina; Siswanta, D.; Solikhah, E.N. Isolation and Antibacterial Activity Test of Lauric Acid from Crude Coconut Oil (Cocos nucifera L.). Procedia Chem. 2016, 18, 132-140. [CrossRef]

8. Hristov, A.N.; Vander Pol, M.; Agle, M.; Zaman, S.; Schneider, C.; Ndegwa, P.; Vaddella, V.K.; Johnson, K.; Shingfield, K.J.; Karnati, S.K.R. Effect of lauric acid and coconut oil on ruminal fermentation, digestion, ammonia losses from manure, and milk fatty acid composition in lactating cows. J. Dairy Sci. 2009, 92, 5561-5582. [CrossRef] [PubMed]

9. Zain, M.; Wijaya Setia Ningrat, R.; Suryani, H.; Jamarun, N. Effect of Various Feed Additives on the Methane Emissions from Beef Cattle Based on an Ammoniated Palm Frond Feeds. In Animal Feed Science and Nutrition-Health and Environment; IntechOpen: London, UK, 2021.

10. Dohme, F.; Machmüller, A.; Sutter, F.; Kreuzer, M. Digestive and metabolic utilization of lauric, myristic and stearic acid in cows, and associated effects on milk fat quality. Arch. Anim. Nutr. 2004, 58, 99-116. [CrossRef]

11. Faciola, A.P.; Broderick, G.A.; Hristov, A.; Leão, M.I. Effects of lauric acid on ruminal protozoal numbers and fermentation pattern and milk production in lactating dairy cows1. J. Anim. Sci. 2013, 91, 363-373. [CrossRef]

12. De Souza, J.G.; Ribeiro, C.V.D.M. Ruminal biohidrogenation and main impact on met the fatty acid profile: A review. Res. Soc. Dev. 2021, 10, e28101321039. [CrossRef]

13. Diaz, H.L.; Karnati, S.K.R.; Lyons, M.A.; Dehority, B.A.; Firkins, J.L. Chemotaxis toward carbohydrates and peptides by mixed ruminal protozoa when fed, fasted, or incubated with polyunsaturated fatty acids. J. Dairy Sci. 2014, 97, 2231-2243. [CrossRef] [PubMed]

14. Reveneau, C.; Ribeiro, C.V.D.M.; Eastridge, M.L.; Firkins, J.L. Interaction of unsaturated fat or coconut oil with monensin in lactating dairy cows fed 12 times daily II. Fatty acid flow to the omasum and milk fatty acid profile. J. Dairy Sci. 2012, 95, 2061-2069. [CrossRef] [PubMed]

15. Machmüller, A.; Kreuzer, M. Methane suppression by coconut oil and associated effects on nutrient and energy balance in sheep. Can. J. Anim. Sci. 1999, 79, 65-72. [CrossRef]

16. Ribeiro, R.D.X.; Oliveira, R.L.; Macome, F.M.; Bagaldo, A.R.; Silva, M.C.A.; Ribeiro, C.V.D.M.; Carvalho, G.G.P.; Lanna, D.P.D. Meat Quality of Lambs Fed on Palm Kernel Meal, a By-product of Biodiesel Production. Asian-Australas. J. Anim. Sci. 2011, 24, 1399-1406. [CrossRef]

17. Da Conceição dos Santos, R.; Alves, K.S.; Mezzomo, R.; Oliveira, L.R.S.; Cutrim, D.O.; Gomes, D.I.; Leite, G.P.; Araújo, M.Y.d.S. Performance of feedlot lambs fed palm kernel cake-based diets. Trop. Anim. Health Prod. 2016, 48, 367-372. [CrossRef] [PubMed]

18. NRC. Nutrient Requirements of Small Ruminants; National Academies Press: Washington, DC, USA, 2007; ISBN 978-0-309-10213-1.

19. Van Soest, P.J.; Robertson, J.B.; Lewis, B.A. Methods for Dietary Fiber, Neutral Detergent Fiber, and Nonstarch Polysaccharides in Relation to Animal Nutrition. J. Dairy Sci. 1991, 74, 3583-3597. [CrossRef]

20. Mertens, D.R. Gravimetric determination of amylase-treated neutral detergent fiber in feeds with refluxing in beakers or crucibles: Collaborative study. J. AOAC Int. 2002, 85, 1217-1240.

21. Licitra, G.; Hernandez, T.M.; Van Soest, P.J. Standardization of procedures for nitrogen fractionation of ruminant feeds. Anim. Feed Sci. Technol. 1996, 57, 347-358. [CrossRef]

22. Weiss, W.P. Predicting Energy Values of Feeds. J. Dairy Sci. 1993, 76, 1802-1811. [CrossRef]

23. Palmquist, D.L.; Jenkins, T.C. Challenges with fats and fatty acid methods. J. Anim. Sci. 2003, 81, 3250-3254. [CrossRef]

24. NRC. Nutrient Requirements of Dairy Cattle, 7th ed.; National Academies Press: Washington, DC, USA, 2001; ISBN 978-0-309-06997-7.

25. Detmann, E.; Silva, L.F.C.; Rocha, G.C.; Palma, M.N.N.; Rodrigues, J.P.P. Métodos para Análise de Alimentos, 2nd ed.; INCT-Ciência Animal: Viçosa, Brazil, 2021. 
26. Chen, X.B.; Gomes, M.J. Estimation of Microbial Protein Supply to Sheep and Cattle Based on Urinary Excretion of Purine Derivatives-An Overview of the Technical Details; University of Aberdeen: Aberdeen, UK, 1992.

27. Bateson, M.; Martin, P. Measuring Behaviour, 4th ed.; Cambridge University Press: Cambridge, UK, 2021 ; ISBN 9781108776462.

28. Polli, V.A.; Restle, J.; Senna, D.B.; Rosa, C.E.; Aguirre, L.F.; Silva, J.H.S. da Comportamento de bovinos e bubalinos em regime de confinamento: I. atividades. Ciência Rural 1995, 25, 127-131. [CrossRef]

29. Bürger, P.J.; Pereira, J.C.; de Queiroz, A.C.; Coelho da Silva, J.F.; Valadares Filho, S.d.C.; Cecon, P.R.; Casali, A.D.P. Comportamento ingestivo em bezerros holandeses alimentados com dietas contendo diferentes níveis de concentrado. Rev. Bras. Zootec. 2000, 29, 236-242. [CrossRef]

30. Dehority, B.A.; Tirabasso, P.A. Effect of ruminal cellulolytic bacterial concentrations on in situ digestion of forage cellulose. J. Anim. Sci. 1998, 76, 2905. [CrossRef]

31. Allen, M.S. Effects of Diet on Short-Term Regulation of Feed Intake by Lactating Dairy Cattle. J. Dairy Sci. 2000, 83, 1598-1624. [CrossRef]

32. Palmquist, D.L.; Jenkins, T.C. Fat in Lactation Rations: Review. J. Dairy Sci. 1980, 63, 1-14. [CrossRef]

33. Mertens, D.R. Kinetics of Cell Wall Digestion and Passage in Ruminants. In Forage Cell Wall Structure and Digestibility; John Wiley \& Sons, Ltd.: Hoboken, NJ, USA, 2015; pp. 535-570.

34. Faciola, A.P.; Broderick, G.A. Effects of feeding lauric acid on ruminal protozoa numbers, fermentation, and digestion and on milk production in dairy cows1. J. Anim. Sci. 2013, 91, 2243-2253. [CrossRef] [PubMed]

35. Dohme, F.; Machmüller, A.; Wasserfallen, A.; Kreuzer, M. Comparative efficiency of various fats rich in medium-chain fatty acids to suppress ruminal methanogenesis as measured with RUSITEC. Can. J. Anim. Sci. 2000, 80, 473-484. [CrossRef]

36. Matsumoto, M.; Kobayashi, T.; Takenaka, A.; Itabashi, H. Defaunation effects of medium-chain fatty acids and their derivatives on goat rumen protozoa. J. Gen. Appl. Microbiol. 1991, 37, 439-445. [CrossRef]

37. Yoon, Y.; Lee, H.; Lee, S.; Kim, S.; Choi, K.-H. Membrane fluidity-related adaptive response mechanisms of foodborne bacterial pathogens under environmental stresses. Food Res. Int. 2015, 72, 25-36. [CrossRef]

38. dos Santos, A.C.R.; de Azevedo, R.A.; Virgínio Júnior, G.F.; Rodriguez, N.M.; Duarte, E.R.; Geraseev, L.C. Effects of macauba cake on profile of rumen protozoa of lambs. Rev. Bras. Zootec. 2017, 46, 251-256. [CrossRef]

39. Enjalbert, F.; Combes, S.; Zened, A.; Meynadier, A. Rumen microbiota and dietary fat: A mutual shaping. J. Appl. Microbiol. 2017, 123, 782-797. [CrossRef] [PubMed]

40. Aguiar, M. do S.M.; Silva, F.F. da; Donato, S.L.R.; Schio, A.R.; de Souza, D.D.; Meneses, M.D.A.; Lédo, A.A. Síntese de proteína microbiana e concentração de ureia em novilhas leiteiras alimentadas com palma forrageira Opuntia. Semin. Ciências Agrárias 2015, 36, 999. [CrossRef]

41. Van Soest, P.J. Nutritional Ecology of the Ruminant; Cornell University Press: Ithaca, NY, USA, 1994; ISBN 9781501732355.

42. Marini, J.C.; Klein, J.D.; Sands, J.M.; Van Amburgh, M.E. Effect of nitrogen intake on nitrogen recycling and urea transporter abundance in lambs12. J. Anim. Sci. 2004, 82, 1157-1164. [CrossRef]

43. Botham, K.M.; Mayes, P. Cholesterol Synthesis, Transport, \& Excretion. In Harper's Illustrated Biochemistry; Rodwell, V.W., Bender, D.A., Botham, K.M., Kennelly, P.J., Weil, P., Eds.; McGraw Hill: New York, NY, USA, 2016.

44. Mohapatra, E.; Priya, R.; Nanda, R.; Patel, S. Serum GGT and serum ferritin as early markers for metabolic syndrome. J. Fam. Med. Prim. Care 2020, 9, 3458. [CrossRef]

45. Towers, N.R.; Stratton, G.C. Serum gamma-glutamyltransferase as a measure of sporidesmin-induced liver damage in sheep. N. Z. Vet. J. 1978, 26, 109-112. [CrossRef]

46. Hrkovic-Porobija, A.; Hodzic, A.; Hadzimusic, N. Functional liver stress in dairy sheep. Indian J. Small Rumin. 2017, $23,194$. [CrossRef] 